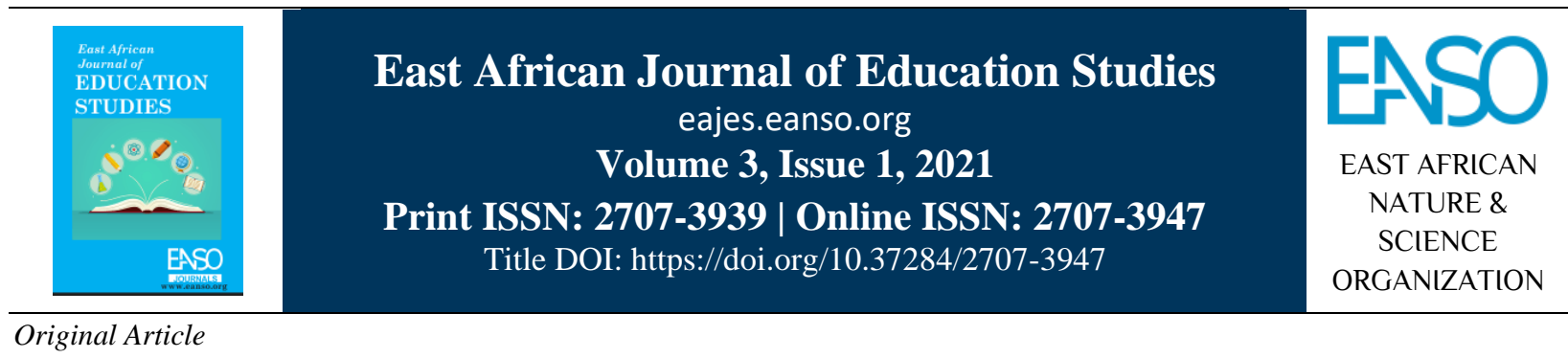

\title{
Preparedness of Schools Management Boards in Curriculum Implementation in Public Primary Schools in Bungoma County, Kenya
}

\author{
Moses Wekesa Soita ${ }^{1} \&$ Protas Fwamba Khaemba ${ }^{2 *}$ \\ ${ }^{1}$ Department of Educational Management, University of Eldoret, P. O. Box 1125-30100, Eldoret, Kenya. \\ ${ }^{2}$ Department of Geography, Kenyatta University P. O. Box 43844-00100 Nairobi, Kenya. \\ *Correspondence Email: fwamba8@gmail.com.
}

Article DOI: https://doi.org/10.37284/eajes.3.1.392

\section{Date Published: ABSTRACT}

26 August 2021 This paper investigates Curriculum Implementation in Public Primary Schools by the Management Boards in Tongeren Sub-County, Bungoma County, Kenya. The study

Keywords: objective was to establish the preparedness of the school management boards in curriculum implementation. The sample size for the study was 136 where Board

School
Management

Boards,

Preparedness,

Curriculum

Implementation,

Public Primary

Schools,

Bungoma

County. members were 92 while teaching staff were 44 . The study adopted both qualitative and quantitative research designs. Data was collected through questionnaires and interview schedules. The questionnaire was used on the education officers, the headteachers, and teachers, while the interview schedules were used on the School Management Boards. Descriptive and inferential analysis techniques were used to analyze the collected data. Cronbach Alpha's measure of internal consistency yielded a reliability coefficient of 0.756 on the questionnaire. Qualitative data collected were analyzed thematically. Quantitative data gathered from the field survey was analyzed using regression on SPSS version 25. The study noted that $96.8 \%$ of the school management boards were not initially trained in curriculum implementation by Kenya Education Management Institute (KEMI). Findings further indicate that the correlation coefficient (R-value) for the model was 0.151 , indicating a low positive relationship between the variables. The Coefficient of determination (R2) was 23\%, implying that the studied variables accounted for $23 \%$ variability in the curriculum implementation in public primary schools at a $95 \%$ confidence interval. This was an indication that members of the school management boards were unlikely to oversee proper curriculum implementation for lack of management skills. Sensitization and organization of regular in-service courses for school management boards on matters of curriculum implementation are recommended.

233 This work is licensed under a Creative Commons Attribution 4.0 International License. 


\section{APA CITATION}

Soita, M. W., \& Khaemba, P. F. (2021). Preparedness of Schools Management Boards in Curriculum Implementation in Public Primary Schools in Bungoma County, Kenya. East African Journal of Education Studies, 3(1), $233-245$. https://doi.org/10.37284/eajes.3.1.392.

\section{CHICAGO CITATION}

Soita, Moses Wekesa, and Protas Fwamba Khaemba. 2021. "Preparedness of Schools Management Boards in Curriculum Implementation in Public Primary Schools in Bungoma County, Kenya”. East African Journal of Education Studies 3 (1), 233245. https://doi.org/10.37284/eajes.3.1. 392.

\section{HARVARD CITATION}

Soita, M. W. and Khaemba, P. F. (2021) "Preparedness of Schools Management Boards in Curriculum Implementation in Public Primary Schools in Bungoma County, Kenya”, East African Journal of Education Studies, 3(1), pp. 233-245. doi: 10.37284/eajes.3.1. 392 .

\section{IEEE CITATION}

M. W. Soita, and P. F. Khaemba, "Preparedness of Schools Management Boards in Curriculum Implementation in Public Primary Schools in Bungoma County, Kenya”, EAJES, vol. 3, no. 1, pp. 233-245, Aug. 2021.

\section{MLA CITATION}

Soita, Moses Wekesa, and Protas Fwamba Khaemba. "Preparedness of Schools Management Boards in Curriculum Implementation in Public Primary Schools in Bungoma County, Kenya". East African Journal of Education Studies, Vol. 3, no. 1, Aug. 2021, pp. 233-245, doi:10.37284/eajes.3.1.392.

\section{INTRODUCTION}

The School Management Boards (SMBs) in Kenya were established based on the guidelines of the Basic Education Act (No. 14 of 2013 section 53-63). This is the body mandated by the Education Act to manage primary and secondary schools. The County Education Board guided the body and approved the members appointed while the Secretary to the board is the Head Teacher or Principal (Herman et al., 2008).

Dervarics and O'Brien (2019) outlined eighty characteristics of effective School Boards, among others; commitment to a vision of high expectations for the school, strong shared beliefs and values about the school, accountability driven, and a collaborative relationship with the school and the community. The school boards should have datasavvy, align and sustain resources to meet school goals and have strong collaboration and mutual trust. Lastly, the school boards should take part in team development and training to build shared values.

School management is the second most important factor that influences students' achievement after teaching quality. Ford (2013) argues that School Boards are responsible for raising school standards. They are responsible for monitoring the overall working of the school which include preparation and recommendation of school development plans and monitoring grants (Palusci \& Covington, 2014).

In many jurisdictions, school boards are responsible for promoting the interests of the schools and ensuring development, quality education and pupils' discipline. They provide for the welfare and rights of pupils. The boards play a supervisory role and in the maintenance of school premises. The boards are in charge of all financial and legal participatory monitoring operations of the school. The Schools Act No. 84 of 1996 gave guidelines for the school governing bodies (SGBs) and the school heads on their roles and responsibilities in managing the school funds. Mestry (2006) observed that a major challenge facing schools is that some members of SGBs and heads had little knowledge of the Schools Act and/or interpreted it wrongly, which resulted in many schools experiencing financial mismanagement.

Members of the Schools Management Boards require skills in keeping Books of Accounts. This was very necessary for accountability and transparency (Khama, 2014). Without this skill, many projects in learning institutions would remain incomplete for a long and stakeholders could not understand why (Orodho, 2013; Owino \& Abagi, 2000). The government was to avail books of accounts before the introduction of Free Primary Education. Seminars and workshops were to be 
organized before handing over the same rather than giving huge amounts of money to Schools Management Boards including the headteachers who had little or no skill of keeping these books.

The Cabinet Secretary should by regulations, according to the Basic Education Act 2013 No. 14 of 2013, prescribe the qualifications for persons who might be appointed to or co-opted into the Board of Management in any basic education institution under this Act. The nominating and appointing authority of a board of management should observe and respect: the ethnic and regional diversity of the people of Kenya, the impartiality and gender equity, appointment and term of chairperson and members, and promotion of special needs education (Owino, \& Abagi, 2000).

However, Mbii et al. (2020) study on the BOM members' training, skills and competence and performance of their responsibilities noted discrepancies in their appointments. The findings indicated that, in some of the school boards, there is a blatant breach of guidelines given by the Ministry. Some BOM members had primary school education as their highest academic qualification against the policy. They observed that the training of the BOM members was not given priority as required by the policy. The study recommends that there is a need to train BOM members on policy interpretation, strategy formulation and financial management for them to be able to manage schools.

Lack of proper curriculum implementation in schools has had adverse effects on school performance in the National Exams in the SubCounty. The Kenya Certificate of Primary Education (KCPE) results for Tongaren SubCounty had been declining since 2015 and were below the County's average mark of 280 (Table 1).

Table 1: Showing KCPE Results (2015-2019)

\begin{tabular}{ll}
\hline Year & Mean Mark \\
\hline 2015 & 229.60 \\
2016 & 245.60 \\
2017 & 228.04 \\
2018 & 230.04 \\
2019 & 232.29 \\
\hline
\end{tabular}

Source: Tongaren Sub-County (2020).

The expected mean mark was 350 marks for one to secure a chance in National schools or 300 marks for County and extra-County schools. The performance shown above was considered a failure because the graduates of this mark could not compete for chances in National or County schools. According to Too, Kimutai and Kosgei (2019) noted that it was the responsibility of headteachers to supervise curriculum implementation in schools, as shown in Figure 1. 
Figure 1: Responsibility of headteachers to supervise on curriculum implementation

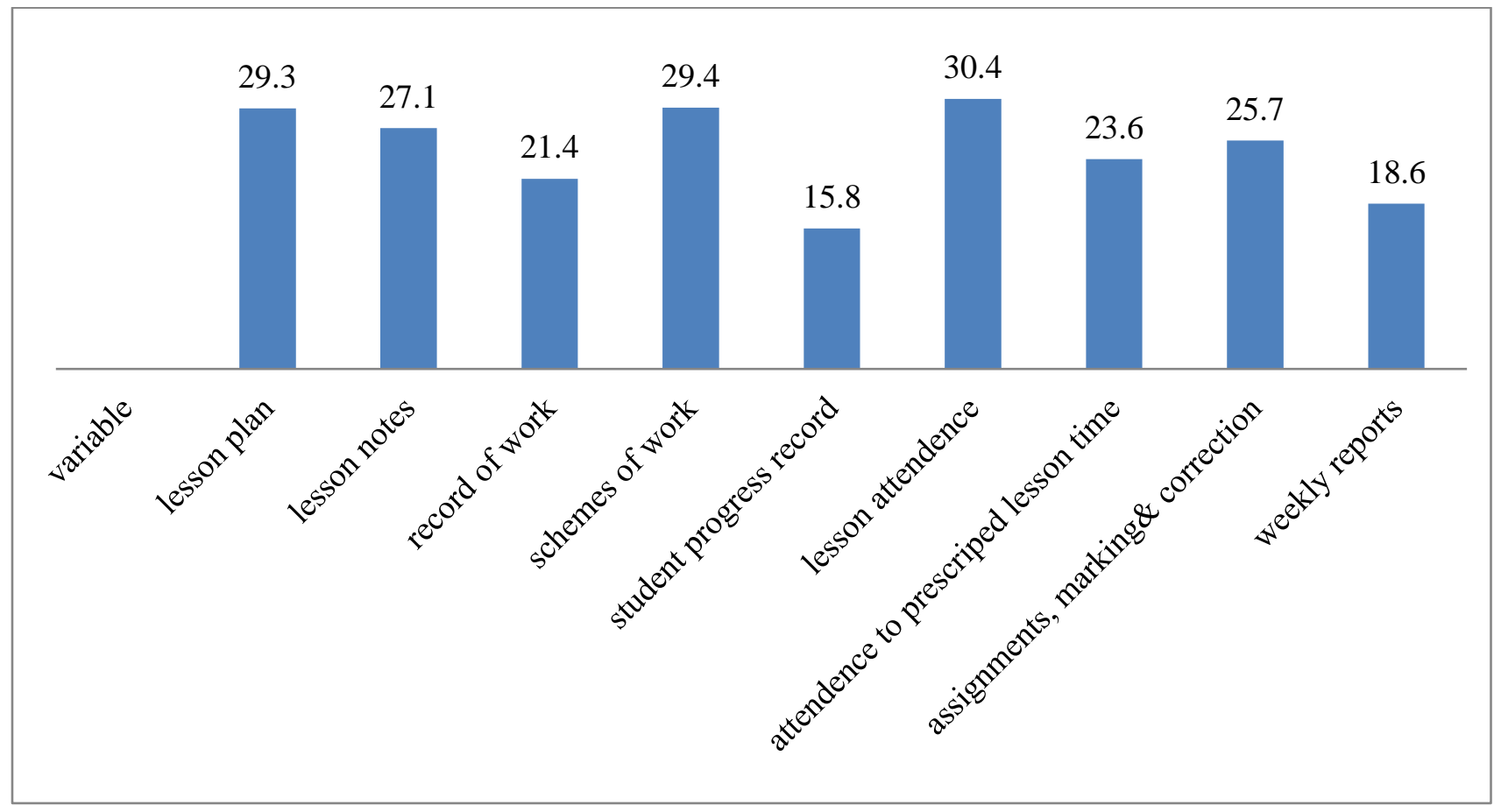

According to Too, Kimutai and Kosgei (2019), school heads and the School Management Boards had failed in their supervisory and monitoring roles in curriculum implementation in schools. They observed that some headteachers had been demoted and others transferred over examination failure between 2015- 2019.

The Kenya Education Management Institute (KEMI) was introduced by the Ministry of Education to train Educational Managers in their managerial skills (Khama, 2014). These educational managers included the Quality Assurance Standards Officers, headteachers and their deputy, senior teachers, and School Management Board members. However, the School Boards' preparedness on quality management capacities and training in providing leadership and good governance in the implementation of the curriculum were not clear.

Despite the importance of having Boards of Management in schools, most of them don't perform their duties and responsibilities as stipulated by the Ministry of Education in curriculum implementation. In Bungoma North Sub -County, the situation is worse to the extent that performance in National Exams is worrying due to poor curriculum implementation. This study, therefore, set out to assess the School Management Boards in curriculum implementation in public primary schools in Bungoma North Sub-County, Kenya. The study objective was to assess the preparedness of the Schools Management Boards in curriculum implementation in 8 key areas; school funds, financial fraud, provision of learning and teaching materials, adequacy in financial management, knowledge on books of accounts, training by KEMI, and commitment and competency by the board.

\section{LITERATURE REVIEW}

Education plays a pivoting role in the development of human civilization. It caters to the needs of society and prepares it for a better future. Ben \& Murundu (2019) carried out a study on indicators and school governance principles. The study shows that there is no single school governance model that is appropriate for all schools, countries, and economic environments. The study results suggest that the board's clear function, sustainable policy, and board charter have significant positive driving forces on school performance.

Tshiunza et al. (2017) observed that in many developing countries, the parents are the main 
source of financing of school operations. The Local School Board (LSB) reform was not only important because of their participatory management of school operations but also in ensuring that school resources enhanced pupils' outcomes. The findings demonstrated that among the components of the governance system of LSB, the competencies of Boards, their control power, and characteristics have a huge impact on student academic performance.

Free Primary Education (FPE) introduced in 2003 by the Government of Kenya enhanced access to education. According to Sessional Paper No. 14 of 2012, the acquisition of learning outcomes in literacy, numeracy, and essential life skills was still low (Wanjohi, 2019).

Cheruto and Benjamin (2010) study examined the management challenges facing the implementation of FPE in Kenya, a case of primary schools in Keiyo District. The study results showed that primary school management faced challenges in the implementation of the program which included shortage of staff, limited financial management skills, and resistance from parents, inadequate physical facilities, and delay in disbursement of funds by the government. The study recommended the training of headteachers in financial management and other managerial skills; accounts clerks to be employed in primary schools to assist in the book-keeping.

Ndiang'ui (2013) study examined the challenges in the management of Free Primary Education funds in public primary schools in Nyahururu District of Laikipia County, Kenya. The study established that a majority of public primary headteachers and school committee members were not trained or inducted on school financial management. This compromised their ability to source school funds, procure the right teaching-learning resources, and audit school accounts. The study results further indicated that irregular inspection of school funds and the management of FPE funds through the DEO's office create room for complacency, corruption, and ineptitude.

According to the Ministry of Education (the Republic of Kenya, 2017), Ksh. 3.9 billion was availed by the World Bank towards Free Primary Education, the British government gave Ksh. 1.6 billion for the project with the treasury on its part pumping Ksh. 2.8 billion to start it. (Kibet, 2017). From the Ministry of Education's disbursement of Ksh. 3 billion, Ksh. 633 was allocated to each pupil, Ksh. 499 was to be spending on instructional material while Ksh. 135 was to be spending on other operational costs in schools. However, school Management Boards and other stakeholders were never prepared by the government on the skills of handling huge amounts of money before the introduction of Free Primary Education in Kenya (Ndian'gui, 2013).

Boards of Management (BOM) play a critical role in ensuring the successful implementation of Constituency Development Funded (CDF) projects in schools in Kenya. They have an oversight monitoring and evaluation role in the implementation of government-funded projects by guidelines set by the Ministry of Education (Ben \& Murundu, 2019). Most of the boards don't perform these roles fully leading to poor performance of CDF projects in secondary schools in Kenya. Most school heads overpower and ignore Boards of Management, leading to the failure of CDF projects to achieve their desired goals in many schools. Some CDF projects are never completed due to the embezzlement of funds by the school heads.

Ben and Murundu (2019) carried out a study to establish the role of Boards of Management in monitoring and evaluation of Constituency Development Funded (CDF) projects in public secondary schools in Teso South Sub-County, Busia County. The study observed that (BOM) doesn't frequently inspect and evaluate financial records in schools. The study recommends that the BOM be given the full mandate of inspecting and evaluating all the school financial records to ensure that school funds are well utilized on the required projects.

Mestry (2006) carried out a study to determine the perceptions of stakeholders on the financial functions of school governing bodies and to develop guidelines for principals and school governing bodies to enable them to manage their school funds efficiently and effectively. The study adopted a qualitative research design based on exploratory, descriptive and contextual nature. The study findings revealed that there was a misconception amongst stakeholders regarding the functions of the 
school governing bodies in managing the schools' funds

Chelulei (2021) carried out the study on Board of Management participation in the implementation of strategic plans in primary schools in Eldoret East Sub-County, Uasin Gishu County, Kenya. The study recommends that knowledge on the Books of Accounts could have been availed to the school boards by the government before the introduction of the Free Primary Education Fund through seminars and workshops. He observed that huge amounts of money were availed to Schools Management Boards who had little or no skills in financial management.

There have been instances of fraud reported at the Ministry of Education on the embezzlement of funds meant for FPE. For instance, in 2003, the British government threatened to withdraw funding the FPE in Kenya, demanding the prosecution of those who misappropriated the funds (Patrick, 2019). This was one of the hindrances to the provision of Universal Free Primary Education (UFPE) and if the trend continued, then it would be difficult for the government to achieve Millennium Development Goals (MDGs. The purpose of this study was to therefore to assess the preparedness of the Schools Management Boards in curriculum implementation in public primary schools in Bungoma North Sub-County, Bungoma County, Kenya.

\section{MATERIALS AND METHODS}

The study was carried out in Bungoma North SubCounty, Bungoma County, Kenya. It has two educational zones (Ndalu and Tongeren) with its headquarters at Tongeren. It is bordered to the south by Bungoma South Sub-County. Trans-Nzoia West Sub-County to the north, Kimilili Sub-County to the west, and Likuyani Sub-County to the East. It is about $15 \mathrm{~km}$ from Kitale town. The Sub-County is cosmopolitan with all communities of Kenya residing there. The road network is fair but impassable during the rainy seasons. The Subcounty is mainly an agricultural area growing maize and beans majorly. The main cash crop in the region is sugarcane. Other crops include sunflower, cassava, sweet potatoes, and Irish potatoes.

The sub-county has both private and public primary schools. The study focused on public primary schools whose performance was wanted (Tongaren Sub-County, 2020). 
Figure 2: Map of Tongaren Sub-County, Bungoma County, Kenya

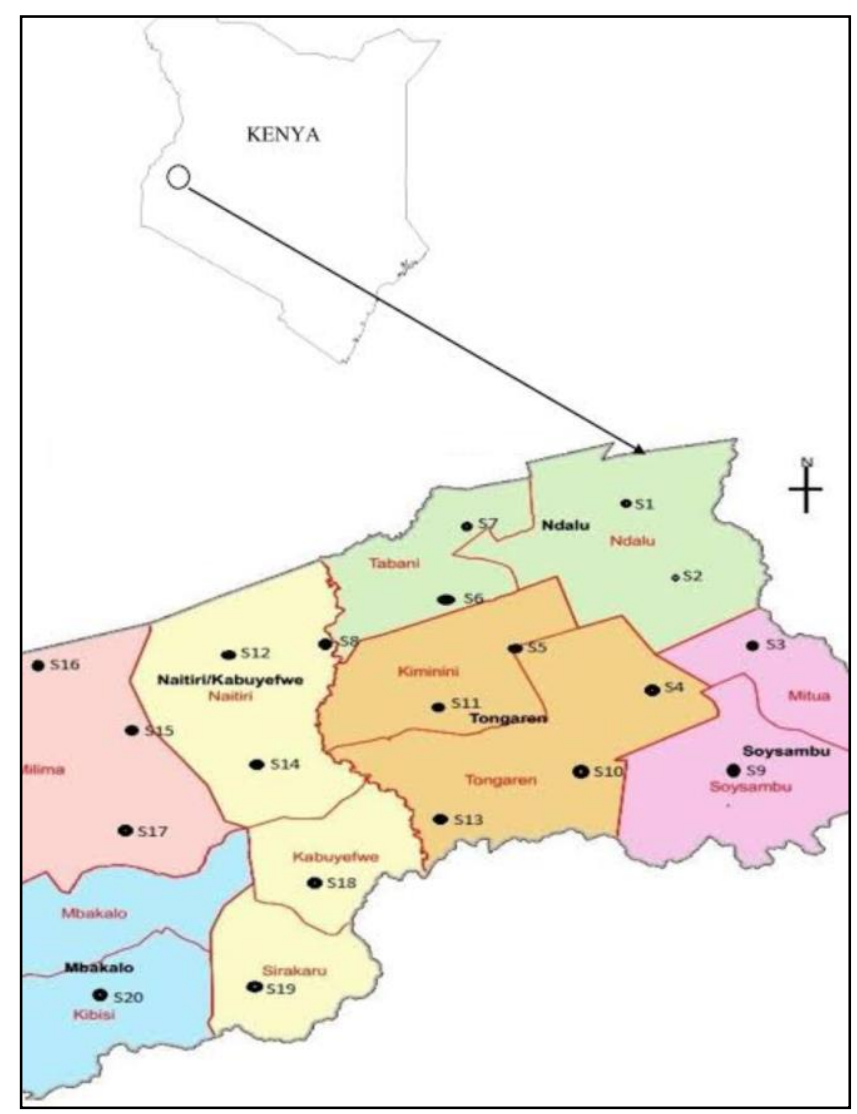

Source: Bungoma County Integrated Development Plan (2013.

This study adopted a mixed-method research design involving both questionnaire and interview schedule. The questionnaire was used on the education officers, the headteachers, and teachers, while the interview schedules were used on the School Management Boards. According to Orodho and Kombo (2002), this design is used when collecting information about people's attitudes, opinions, habits, or any educational or social issues. The study assessed the preparedness of Schools Management Boards concerning curriculum implementation, recording their findings, analyzing and interpreting them. This type of design was applied to this study because the information was collected from a few schools and the results generalized overall public primary schools in the country.

Hypothesis testing to determine the significant relationships between the variables used in the study was done through correlation analysis at a $95 \%$ level of significance. This statistical technique was appropriate for the study because it includes analyzing several variables when the focus is on the relationship between a dependent variable and one or more independent variables (Pickard, 2013).

Therefore, a regression model was used to determine the relationship between the factors $(\mathrm{Xi}$, $\mathrm{X} 2$.) and curriculum implementation (Y),

$$
\begin{aligned}
& Y=\beta_{0}+\beta_{1} X_{1}+\beta_{2} X_{2}+\beta_{3} X_{3}+\beta_{4} X_{4}+ \\
& \beta_{5} X_{5}+\beta_{6} X_{6}+\beta_{7} X_{7}+\beta_{8} X_{8}+\varepsilon
\end{aligned}
$$

Where $\mathrm{Y}=$ curriculum implementation; $\beta 1 \ldots \beta 8=$ Coefficients of determination X1 = School Funds; X2 = Learning/Teaching Materials; X3 = Financial Fraud; X4 = Adequacy in Financial Management; $\mathrm{X} 5=$ Knowledge of Books of Account; X6 = Training by KEMI; X7 = Seminars and Workshops; $\mathrm{X} 8=$ Commitment and Competency; $\mathcal{E}=$ Error term

239 | This work is licensed under a Creative Commons Attribution 4.0 International License. 


\section{DATA ANALYSIS, DISCUSSION, AND PRESENTATION OF FINDINGS}

Data on this aspect are presented in Table 2.

Table 2: Preparedness of School Management Boards in Curriculum Implementation

\begin{tabular}{lllllllllll}
\hline Variables on boards supervision & SA & & $\mathbf{A}$ & & $\mathbf{U}$ & & $\mathbf{D}$ & & SD \\
& $\mathbf{F}$ & $\mathbf{\%}$ & $\mathbf{F}$ & $\mathbf{\%}$ & $\mathbf{F}$ & $\boldsymbol{\%}$ & $\mathbf{F}$ & $\boldsymbol{\%}$ & $\mathbf{f}$ & $\boldsymbol{\%}$ \\
\hline School funds & 102 & 75.0 & 20 & 14.7 & 0 & 0.0 & 14 & 10.3 & 0 & 0.0 \\
Provision of learning and teaching materials & 20 & 14.7 & 30 & 22.1 & 4 & 2.9 & 82 & 60.3 & 0 & 0.0 \\
Financial fraud & 88 & 64.7 & 0 & 0.0 & 4 & 2.9 & 22 & 16.2 & 22 & 16.2 \\
Adequacy in financial management & 88 & 64.7 & 4 & 2.9 & 0 & 0.0 & 22 & 16.2 & 22 & 16.2 \\
Knowledge on books of accounts & 12 & 8.8 & 0 & 0.0 & 0 & 0.0 & 22 & 16.2 & 102 & 75.0 \\
Training by KEMI & 0 & 0.0 & 0 & 0.0 & 4 & 2.9 & 116 & 85.3 & 16 & 11.8 \\
Seminars and workshops. & 0 & 0.0 & 0 & 0.0 & 0 & 0.0 & 122 & 89.7 & 14 & 10.3 \\
Commitment and competency & 22 & 16.2 & 4 & 2.9 & 0 & 0.0 & 100 & 73.5 & 10 & 7.4 \\
\hline
\end{tabular}

Table 2 shows the preparedness of school management boards in the implementation of the school curriculum. The study results indicated that $75 \%$ of Schools had SMBS as overall supervisors of public schools which were funded by the Ministry of Education, constituency development fund, and non-governmental organizations. This raised the question of how adequately the members of SMBs were prepared in carrying out their supervisory role of the funds channeled to schools. Furthermore, the SMBs' financial management skills were brought to question on whether the SMB members had adequate knowledge on the use of the channeled funds to implement the primary school curriculum.

The study results indicate that $60.3 \%$ of learning and teaching materials were not provided by the Ministry in public primary schools with the involvement of SMBs (see Table 2). This was attributed to the fact that the primary school enrolment was far much beyond the government projection and provision of teaching and learning material through various vote heads stipulated in the free primary education was not adequate. This is contrary to the government's initiative of teaching/learning materials in the 1980s through the Kenya Equipment Scheme where primary schools were adequately provided with teaching/learning materials such as wall charts, maps, models, textbooks, exercise books, rules, geometrical sets and art, and craft equipment. The government provision of teaching/learning materials was limited to exercise books and course books. The textbook procurement by the government fund was conditioned by the predetermined list available in the Orange Book updated every year. The challenges were that some useful books were not captured in the Orange Books and SMB members were not allowed to authorize the purchase of such books, thus affecting the implementation of the curriculum.

The study results show that $83.8 \%$ indicated massive fraud in public primary schools (see Table 2). This implied that the school management boards were not keen on the correct expenditure of school funds leading to improper implementation of the school curriculum since funds were not spent as stipulated in putting up infrastructure and procuring materials to boast smooth learning. This massive fraud was alluded to tendering and procurement issues, particularly when it came to awarding of CDF bursaries to students and government funding projects by the boards. The boards had conflicting interests, which led to a lack of impartiality and fairness in the entire process. Procurement of textbooks and exercise books also provided a loophole as a source of fraud and corruption whereby members expected kickbacks from those awarded tenders to supply the goods. This study confirms Kurniawan et al. (2020) that noted massive fraud resulting from inadequate $s$ monitoring mechanisms by the School Management Boards 
The preparation of members of the SMBs in handling finances is a priority in ensuring that funds meant for curriculum implementation through the provision of teaching, learning, and evaluation materials are effectively done. Therefore, the study sought to establish whether all school management board members had adequate skills to handle huge amounts of money. The study found out that the majority $(67.6 \%)$ of SMBs had little or no skills in handling huge amounts of money (see Table 2). Lack of adequate skills in handling finances may provide a loophole for misappropriation of funds and affect curriculum implementation in schools. Some members of SMBs may take the ignorance of other members regarding financial management as an advantage of embezzling funds especially by the heads of the institutions. The schools, whose board members were knowledgeable in financial matters, had effective and efficient curriculum implementation. This study result confirms the study by Abagi and Olweya (1999) and Ndian'gui (2013) who observed that lack of financial management skills by the school boards provided loopholes for embezzlement of school funds.

The study results indicated that $91.2 \%$ of school boards did not know financial matters while only $8.8 \%$ of the board members knew books of accounts (see Table 2). This was an indication that members of school management boards lacked adequate financial skills and this was likely to hamper the smooth implementation of the school curriculum since procurement of teaching/learning materials was not effectively done. The study results confirm the study by Hess (2010) that good governance and financial accountability in a school are dictated by the quality of its managers.

On training and induction of school management boards, the study indicated that $96.8 \%$ had not been trained by KEMI (see Table 2). This was an indication that members of the schools' management boards were unlikely to oversee proper curriculum implementation for lack of management skills. Seminars and workshops are important in carrying out duties by school management boards. The study indicates that all school boards had not attended seminars and workshops. The lack of seminars and workshops had negatively impacted the curriculum implementation in public primary schools in the region. The study results confirm the study by Osukuku and Zadock Murundu (2019), who had noted that school management boards could not monitor and evaluate Constituency Development Funded (CDF) projects in public secondary schools in Teso South Sub-County.

The study also sought to establish whether all School Management Board members are committed and competent in managing curriculum in public primary schools. It was found out that $80.9 \%$ of the School Management Board members were not committed and competent in managing curriculum in public primary schools (see Table 2). The lack of commitment by the school boards had negatively impacted curriculum implementation in public primary schools. The study results confirm the study by Mbii et al. (2020) who noted discrepancies in the appointments of BOM members, lack of training, and capacity building and competence are affected the performance of their responsibilities.

\section{Inferential Results and Hypothesis Testing}

$\mathrm{H}_{\mathrm{O1}}$ : There is a statistically significant relationship between BOM preparedness and curriculum implementation in public primary schools.

This section reports the results of the hypothesis testing indicating the relationships between curriculum implementation and various variables (school funds, learning/teaching materials, financial fraud, adequacy of financial management, knowledge on books of account, training by KEMI, seminars, and workshops, and commitment and competency of BOM members) in the study objective and the hypothesis based on the study objective (Table 3). An alpha value of $\alpha<0.05$ was used in the regression statistical inferential tests. Significance test qualification was nearness to 0.000 for regression test. The value of $\mathrm{R}^{2}$ adj was used. Significance test qualification was based on a percentage of $\mathrm{R}^{2}$ adj and within 0.3 to 0.7 ranges for Beta weight value (Nabiswa, 2018). 
East African Journal of Education Studies, Volume 3, Issue 1, 2021

Article DOI: https://doi.org/10.37284/eajes.3.1.392

Table 3: Model Summary

\begin{tabular}{|c|c|c|c|c|c|c|c|c|c|}
\hline \multirow[t]{2}{*}{ Model } & \multirow[t]{2}{*}{$\mathbf{R}$} & \multirow[t]{2}{*}{$\mathbf{R}^{2}$} & \multirow{2}{*}{$\begin{array}{l}\text { Adjusted } \\
\mathbf{R}^{2}\end{array}$} & \multirow{2}{*}{$\begin{array}{l}\text { Std. } \\
\text { Err. }\end{array}$} & \multicolumn{5}{|c|}{ Change Statistics } \\
\hline & & & & & $\begin{array}{l}\text { R Square } \\
\text { Change }\end{array}$ & F Change & & df2 & $\begin{array}{ll}\text { Sig. } & \text { F } \\
\text { Change } & \end{array}$ \\
\hline 1 & $151^{\mathrm{a}}$ & .23 & .020 & .473 & .521 & 0.552 & 4 & 51 & .00 \\
\hline
\end{tabular}

Findings in Table 3 indicate that the regression coefficient (R-value) for the model was 0.151 . Rvalue is used to show the strength and direction of the relationship between the variables. In this case, the R-value of .151 indicates a low positive relationship between Curriculum Implementation and variables of school management boards (Nabiswa, 2018). The Coefficient of determination $\left(\mathrm{R}^{2}\right)$ was found to be $0.23(23 \%)$. This implies that the 8 variables studied which were; school funds, learning/teaching materials, financial fraud, adequacy of financial management, knowledge on books of account, training by KEMI, seminars and workshops and commitment and competency, accounted for $23 \%$ variability in the curriculum implementation at $95 \%$ confidence interval.

Table 4 shows regression of curriculum implementation against various variables used in the study.

Table 4: Regression Analysis

\begin{tabular}{|c|c|c|c|c|c|c|}
\hline \multirow{2}{*}{\multicolumn{2}{|c|}{$\begin{array}{l}\text { Coefficients } \\
\text { Model }\end{array}$}} & \multirow{2}{*}{\multicolumn{2}{|c|}{$\begin{array}{l}\text { Unstandardized } \\
\text { Coefficients }\end{array}$}} & \multirow{3}{*}{$\begin{array}{l}\text { Standardized } \\
\text { Coefficients } \\
\text { Beta }\end{array}$} & \multirow{3}{*}{$\mathbf{t}$} & \multirow{3}{*}{ Sig. } \\
\hline & & & & & & \\
\hline & & \multirow{2}{*}{$\begin{array}{l}\text { B } \\
2.786\end{array}$} & \multirow{2}{*}{$\begin{array}{l}\text { Std. Error } \\
.867\end{array}$} & & & \\
\hline 1 & (Constant) & & & & 3.215 & .002 \\
\hline & School funds & .323 & .319 & -.057 & -.559 & .578 \\
\hline & Learning/teaching materials & .378 & .225 & .248 & 2.220 & .029 \\
\hline & Financial fraud & -.395 & .341 & -.060 & -.586 & .559 \\
\hline & Adequacy of financial management & .354 & .240 & -.049 & -.451 & .653 \\
\hline & Knowledge on books of account & .251 & .235 & -.065 & -.450 & .654 \\
\hline & Training by KEMI & .472 & .242 & -.079 & -.743 & .460 \\
\hline & Seminars and workshops & .396 & .152 & .085 & .758 & .450 \\
\hline & Commitment and competency & .458 & .276 & .031 & .216 & .830 \\
\hline
\end{tabular}

a. Dependent Variable: Curriculum Implementation

Applying the regression formula:

$$
\begin{aligned}
Y=\beta_{0}+\beta_{1} X_{1} & +\beta_{2} X_{2}+\beta_{3} X_{3}+\beta_{4} X_{4}+\beta_{5} X_{5} \\
& +\beta_{6} X_{6}+\beta_{7} X_{7}+\beta_{8} X_{8}+\varepsilon
\end{aligned}
$$

The established model for the study was:

$$
\begin{aligned}
Y=2.786+ & 0.323 X_{1}+-0.378 X_{2}+0.395 X_{3} \\
& +0.354 X_{4}+0.251 X_{5}+0.472 X_{6} \\
& +0.396 X_{7}+0.458 X_{8}+\varepsilon
\end{aligned}
$$

The regression equation above established that taking all factors into account school funds at zero curriculum implementation was 2.786. However, a unit increase in school funds would result in a 0.323 or $32.3 \%$ increase in preparedness in curriculum implementation (see Table 4). This is a moderate relationship as the beta weight is within the decision criterion of the coefficient range 0.3 to 0.7 . This value $(\beta 1=0.323)$ implies that the variance in school funds significantly accounted for the preparedness in curriculum implementation.

242 | This work is licensed under a Creative Commons Attribution 4.0 International License. 
It was also noted that a unit increase in learning/teaching materials would result in a .378 or $37.8 \%$ increase in curriculum implementation; thus, showing a moderate relationship. This value $(\beta 1=$ 0.378 ) implies that the variance in learning/teaching materials significantly accounted for the curriculum implementation (see Table 4).

Taking all factors into account, a unit increase in financial fraud would result in a -0.395 or $39.5 \%$ reduction in preparedness in curriculum implementation (see Table 4). This is a moderate relationship as the beta weight is within the decision criterion of the coefficient range -+0.3 to -+0.7 . This value $(\beta 1=-0.395)$ implies that the variance in learning/teaching materials significantly accounted for the Curriculum implementation.

A unit increase in the adequacy of financial management would result in a .354 or $35.4 \%$ increase in curriculum implementation (see Table $4)$. This value $(\beta 1=0.354)$ implies that the variance in learning/teaching materials significantly accounted for the Curriculum implementation. In addition, a unit increase in knowledge on books of account would result in a .251 or $25.1 \%$ increase in curriculum implementation. This value $(\beta 1=0.251)$ implies that the variance in learning/teaching materials significantly accounted for the Curriculum implementation.

The regression equation above established that taking all factors into account the training by KEMI at zero curriculum implementation was 2.786 . However, a unit increase in training by KEMI would result in a .472 or $47.2 \%$ increase in curriculum implementation (see Table 4). This value $(\beta 1=0.472)$ implies that the variance in learning/teaching materials significantly accounted for the Curriculum implementation. Besides, a unit increase in seminars and workshops would result in a .396 or $39.6 \%$ increase in curriculum implementation. This value $(\beta 1=0.395)$ implies that the variance in learning/teaching materials significantly accounted for the Curriculum implementation. Lastly, a unit increase in commitment and competency would result in a .458 or $45.8 \%$ increase in curriculum implementation. This value $(\beta 1=0.458)$ implies that the variance in learning/teaching materials significantly accounted for the curriculum implementation.

\section{CONCLUSION AND RECOMMENDATIONS}

Public primary schools had put in place school management boards as stipulated by the Ministry of Education requirement. However, the preparedness of these boards in implementing school curriculum was still a subject of investigation. Thus, in-service courses on curriculum implementation should be organized on a regular basis to empower teachers and board members to effectively implement the curriculum.

Although school management boards have tried to ensure that curriculum implementation is done accordingly, there is still much to be desired. This includes their training in matters of curriculum implementation to the provision of teachinglearning resources. School Management Board members can effectively deliver better in their duties if they have been inducted or trained in what to do. However, on job learning leads to errors that stand in the way of curriculum implementation.

Decision making should be involved by all stakeholders. There should be collective decision making especially with regard to the facilitation of curriculum implementation. The motivation of learners and teachers was not satisfactory on the part of school management boards. This hindered implementation of the curriculum.

\section{REFERENCES}

Abagi, O. \& OLweya, J. (1999). Achieving Universal education in Kenya by 2015: Where the Reality lies. Institute of Policy Analysis and Research, 17(99).

Ben, P. O., \& Murundu, Z. O. (2019). Role of Boards of Management (BOM) in Monitoring and Evaluation of Constituency Development Funded (CDF) Projects in Secondary Schools. South Asian Research Journal of Business and Management, 1(1), 11-22.

Chelulei, B. K. (2021). Board of Management participation in implementation of strategic plans in primary schools in Eldoret East SubCounty, Uasin Gishu County, Kenya. Unpublished Doctoral Dissertation, university of Eldoret, Kenya. 
Cheruto, K. L., \& Benjamin, K. W. (2010). Management challenges facing implementation of free primary education in Kenya: A case of Keiyo District. International Journal of Educational Administration and Policy Studies, 2(5), 71-76.

Covington, C. D. (2011). Lagging in a race: The impact of teacher morale on student achievement. Unpublished doctoral dissertation. Capella University, USA.

Dervarics, C., \& O'Brien, E. (2019). Eight Characteristics of Effective School Boards. Center for public education.

Ford, M. (2013). The impact of school board governance on academic achievement in diverse states. Doctoral dissertation, The University of Wisconsin-Milwaukee.

Government of Kenya (2012) Session paper No. 14 of 2012 on Reforming Education and Training Sectors in Kenya.

Herman, R., Dawson, P., Dee, T., Greene, J., Maynard, R., Redding, S., \& Darwin, M. (2008). Turning Around Chronically Low-Performing Schools. IES Practice Guide. NCEE 20084020. National Center for Education Evaluation and Regional Assistance.

Khama, N. R. (2014). Views of board members on management of schools: A case study of Captivity Educational Region of Namibia. Unpublished M.Ed. Thesis. University of Namibia, Namibia.

Kibet, S. P. (2017). Constraints on Pupils Transition from primary to public secondary schools in Kericho County, Kenya. Doctoral dissertation, Kenyatta University, Kenya.

Kombo D. and Tromp D. (2006). Proposal and Thesis Writing. An Introduction. Paulines Publications Africa.

Mbii, M. M., Magoma, C. M., \& Waweru, S. N. (2020). Composition and Practices of Secondary School Boards of Management: Lessons from Kenya. American Journal of Educational Research, 8(5), 299-303.
Mbii, M. M., Magoma, C. M., \& Waweru, S. N. (2020). Composition and Practices of Secondary School Boards of Management: Lessons from Kenya. American Journal of Educational Research, 8(5), 299-303.

Mestry, R. (2006). The functions of school governing bodies in managing school finances. South African Journal of education, 26(1), 27-38.

Mestry, R. (2006). The functions of school governing bodies in managing school finances. South African journal of education, 26(1), 27-38.

Momanyi, C. (2019). Ethical issues in the Basic Education Act No. 14 of 2013: an Aristotelian interpretation. Doctoral dissertation, Strathmore University, Kenya.

Ndian'gui, R. M. (2013). Challenges in management of free primary education funds in public primary school in Nyahururu District, Laikipia County, Kenya. Unpublished doctoral dissertation, Kenyatta University.

Nkundabanyanga, S. K., Tauringana, V., \& Muhwezi, M. (2015). Role of governing boards and perceived performance of secondary schools: preliminary evidence from a developing country. International Journal of Public Sector Management, 28(3), 221-239.

Orodho, A. and Kombo D. (2002), Key Issues influencing the level of Community Participation in projects: Research Methods. Kenyatta University Press- Nairobi

Orodho, J. A. (2014). Policies on free primary and secondary education in East Africa: Are Kenya and Tanzania on course to attain Education for All (EFA) Goals by 2015. International Organization of Scientific Research (IOSR) Journal of Humanities and Social Sciences 19(1), 11-20.

Owino, W., \& Abagi, O. (2000). Cost sharing in education and health in Kenya. Draft, Desk study commissioned by the Department for International Development (DFID)-Eastern 
Africa, Institute of Policy Analysis and Research.

Palusci, V. J., \& Covington, T. M. (2014). Child maltreatment deaths in the US national child death review case reporting system. Child abuse \& neglect, 38(1), 25-36.

Patrick, A. O., (2019). Headteachers' preparedness in managing finances in public primary schools in Rachuonyo North Sub County, Homa Bay County, Kenya. Unpublished Masters Dissertation., Kenyatta University, Kenya

Tshiunza, C. L., Xin, L., \& Gracia, P. E. (2017). Impact of Governance System of Local School Boards on Pupils' Academic Performance in RD Congo Pilot Primary Schools. Education, 7(6), 124-137.

Wanjohi, S. W. (2019). Effects of free primary education on factors influencing quality of instruction in public primary schools in Nyandarua north sub county, Kenya. Unpublished PhD. Dissertation., Egerton University, Kenya. 